\title{
Wuthering Heights and the UNFORgIVABLE SIN
}

The two dreams Lockwood experiences early in Wuthering Heights-the first of a visit to Gimmerton Kirk, and the second of a visit from the ghost-child Catherine-have recently received critical attention from Ruth M. Adams and Edgar Shannon. ${ }^{1}$ Of the two interpretations Shannon's seems the most convincing in that it offers the only plausible source for the Biblical allusion in the first dream; but in discussing the relationship of the dream sermon and its title to the tragedy of Heathcliff and Catherine, Shannon ignores significant aspects of the dream itself, and consequently the value of his interpretation seems impaired somewhat, like Miss Adams's, by its own ingenuity.

The preacher that Lockwood hears in the first dream is Jabes Branderham, and the sermon is entitled "Seventy Times Seven and the First of the Seventy-first." Shannon identifies the sermon's text as Matt. $18: 21-22$. In this passage Peter asks Jesus, "Lord, how oft shall my brother sin against me, and I forgive him? Till seven times?" and Jesus answers, "I say not unto thee Until seven times: but, Until seventy times seven." "The First of the Seventy-first," then, Shannon asserts, "advances the idea of an unpardonable sin beyond the ordinary scale of human wrongs." The subsequent nightmare, he continues, connects this idea with Catherine, who appears as an outcast, and we are asked to believe that it is she who has committed the unforgivable sin by marrying Edgar and denying the "natural and elemental affinity" inherent in her love for Heathcliff. "Adhered to, [love] is at once the source of joy and harmony; rejected or subverted, it becomes the fountainhead of enmity and strife."

One cannot challenge Shannon's assertion that thematically Wuthering Heights displays the "destructive consequences of thwarted love"; but it seems both unfair and inexact to imply that the guilt devolves upon Catherine exclusively. Moreover such an interpretation does not seem to be substantiated by a close reading of the literal and symbolic action of Lockwood's first dream. Shannon implies that the nature of the unpardonable sin is merely hinted at rather than defined, and that the reader is left to infer

\footnotetext{
1"Wuthering Heights: The Land East of Eden," NCF, XIII (June, 1958), 58-62; "Lockwood's Dreams and the Exegesis of Wuthering Heights," NCF, XIV (September, 1959), 95-109.
} 
its nature from the second dream and from the action that follows. In fact, however, through a curious kind of logical paradox, the unpardonable sin is defined within the action of the dream itself. Not long after Branderham's sermon opens Lockwood begins to fidget, laboring under the four hundred and ninety heads of discourse-each in itself the length of a separate sermon. Finally, when Branderham reaches the "First of the Seventy-first" Lockwood can bear it no longer; he rises and denounces Branderham as

the sinner of the sin that no Christian need pardon [emphasis supplied]. Seventy times seven times have I plucked up my hat and been about to depart-Seventy times seven times have you preposterously forced me to resume my seat. The four hundred and ninety-first is too much. Fellow-martyrs, have at him!

Branderham's reply is equally significant as he turns the congregation back upon Lockwood.

"Thous art the Man!" cried Jabes. . . "Seventy times seven times didst thou gapingly contort thy visage-seventy times seven times did I take counsel with my soul-Lo, this is human weakness; this also may be absolved! The First of the Seventy-first is come [emphasis supplied]. Brethren, execute upon him the judgment written . . " (p. 23). ${ }^{2}$

Lockwood himself, in other words, commits (in the dream at least) the unforgivable sin in accusing Branderham of that sin no Christian need pardon. That is, the unforgivable sin is to accuse another of committing the unforgivable sin-or, more simply put, the absence of forgiveness, of forbearance, of mercy. Each man forgives the other four hundred and ninety times, as Jesus enjoins, but neither has the charity to forbear the four hundred and ninetyfirst offense; each then denounces the other, and chaos erupts"Every man's hand was against his neighbour" (p. 24).

Moreover, it is manifestly forgiveness, and not, as Shannon suggests, sin that Jesus is talking about; Peter in using the verb sin refers to a personal offense, not to mortal transgression; and of course what Jesus is urging is perpetual forgiveness, perpetual charity, only he phrases it in finite terms.

The relation of the dream and its Biblical source to the tragedy

\footnotetext{
${ }^{2}$ Parenthetical page references are to the Rinehart Edition of Wuthering Heights, ed. Mark Schorer (New York, 1950).
} 
that follows would seem obvious. It is the want of forgiveness-or phrased positively, it is vengeance-that disrupts the moral and social order of Wuthering Heights. Hindley cannot forgive Heathcliff for usurping the love of his father; so once he is master of the Heights, he sees that Heathcliff is methodically humiliated and degraded. Heathcliff's degradation in turn enforces a physical and psychological separation from Catherine which preordains her marriage to Edgar Linton. When Heathcliff acquires his fortune, he uses the power it affords to avenge himself against Hindley, whom he easily corrupts and destroys; against Hareton and Catherine, the children, who of course are innocent; against Isabella, who is equally blameless; and through all of these, against Edgar Linton, whom he hates not just as a rival but as an embodiment of everything effete and conventional that erodes Catherine's spirit and finally destroys her. Father is turned against son, brother against sister, servant against master, husband against wife, lover against lover-“Every man's hand was against his neighbour."

Catherine is really less a perpetrator than a victim of this turmoil. She shares the guilt of course because her union with Edgar is the act which hastens the tragedy. But hers is an error in judgment rather than a mortal transgression; she marries Edgar in good faith, naively assuming that she can preserve her intense sibling affinity with Heathcliff and perhaps redeem him (and herself) as well. But neither man can forgive her for loving the other and what he represents. In his last interview with Catherine, Heathcliff tells her, "It is hard to forgive, and to look at those eyes, and feel those wasted hands. . . . I forgive what you have done to me. I love my murderer-but yours! How can I?" (p. 171). Torn between the two men, who inspire contrary impulses within her, she grows weak-almost as an act of will-and ultimately dies. When she appears to Lockwood as a ghost and an outcast, his cruelty to her is merely a vivid physical image of the emotional torment she has been made to suffer during her mortal existence.

Among those whom Catherine loves there is no one who can forgive her human error; there is love abundant for her, but it is always conditional love that demands and punishes. Young Catherine and Hareton, we are led to believe, eventually come to love with patience and understanding, but only after Heathcliff's influence is removed. And Heathcliff's rancor merely epitomizes the chief moral defect of all of the characters concerned. That de- 
fect would seem to be not so much the denial of love that Shannon suggests as love's failure to attain charity, to achieve moral fulfillment as well as emotional intensity.

VEREEN M. BELL

Vanderbilt University,

Nashville, Tennessee

\section{LEGEND AND SYMbol IN HARDY's "The Three Strangers"}

In a recent article, William Van O'Connor maintained that "Writers tend to have a persistent view of things throughout their poetry or fiction, and knowing their work as a whole one can often get a clue to the meaning of any individual part of their work." Using this approach, O'Connor forced Hardy's "The Three Strangers" into the established pattern of cosmic irony-"seeing human affairs not as they appear to human participants but from great distances of time and space. A human struggle viewed close up has intensity; viewed from a great distance the struggle will seem rather pointless, for time and space cause any human concern to dwindle into insignificance."' Several aspects of the story, however, do not easily fit this pattern; Albert Guerard's belief that "Hardy's novels, read in sequence, are by no means uniformly gloomy"s may be a more accurate approach to "The Three Strangers."

The story of the condemned man, Timothy Summers, is widespread "in the country about Higher Crowstairs." In fact, Hardy presents the story as a well-known legend, an integral part of the lives of the people. Though the cosmic irony theory suggests that men's actions will seem pointless when viewed from a great distance, Hardy indicates the condemned man's struggle has an intensity and meaning that have not "dwindled into insignificance," even after fifty years. If the story had been forgotten or if the legend had involved a pessimistic view of life, then one could interpret the entire narrative in terms of cosmic irony. However, neither of these were the case. The simple story evolved into a legend and then, due to Hardy's craft, into art.

\footnotetext{
${ }^{1}$ O'Connor, "Cosmic Irony in Hardy's 'The Three Strangers,'” The English Journal, XLVII (May, 1958), 249.

2 O'Connor, p. 250.

${ }^{3}$ Guerard, Thomas Hardy, p. 2.
} 